\title{
"NO ESPAÇO INTERIOR DE CADA POEMA": O DIÁFANO E O PALPÁVEL NAS “ARTES POÉTICAS" DE SOPHIA DE MELLO BREYNER ANDRESEN
}

Elisa Andrade Buzzo

Resumo: Este ensaio busca identificar, apresentar e discutir conteúdos e conceitos dos cinco textos "Arte poética", da poeta portuguesa Sophia de Mello Breyner Andresen. Uma sintética e pontual retrospectiva do conceito inicial de "arte poética" e a leitura de uma seleção de poemas da autora permeiam essa sondagem pelo sentido de suas "Artes poéticas". Assim, como pré-requisito, é realizada uma breve retomada de significados do termo "arte poética", inclusive sendo tratados alguns pontos da Arte Poética de Horácio, a chamada "Carta aos Pisões". Ainda, nessa contextualização, fazemos uma referência à fundamental Poética, de Aristóteles, e ao poema Arte Poética, de Nicolas Boileau-Despréaux. Em seguida, são esmiuçadas sequencialmente as "Artes poéticas" de Sophia de Mello, pequenos textos nos quais, de modo geral, essa poeta tece considerações sobre seu processo de escrita e seu pensamento sobre poesia. Concomitantemente, são colocados em discussão alguns poemas da autora, em termos tanto analíticos quanto comparativos às suas "Artes poéticas", tendo em vista os tópicos: desígnios do fazer poesia, entendimento da própria poesia, do lugar e do papel do poeta, assim como a relação que se coloca entre poesia e poeta. Será uma oportunidade para ponderar de qual forma alguns de seus poemas se relacionam com o ideário de suas "Artes poéticas". A princípio, serão poéticas ligadas à exatidão, à objetividade frente ao real, à atitude racionalizada, à postura de economia e síntese no discurso. Entretanto, observamos que no seu pensamento sobre poesia há certezas palpáveis, como também aspectos cercados por intuição e volatilidade.

Palavras-chave: Artes poéticas. Poética. Poesia portuguesa século XX.

Abstract: This essay looks to identify, present and discuss the contents and concepts underlying the five texts entitled "Arte poética" by the Portuguese poet Sophia de Mello Breyner Andresen. This work is permeated through the sense of her "Artes poéticas" by the reading of a selection of poems by the author and by a synthetic and focused retrospective of the initial concept of "the poetic art". Thus, as a pre- 
requisite, we carry out a brief overview of the meanings of the concept of "the poetic art", including the treatment of a few points of Horatio's Poetic Art, the so-called "Letter to the Pisions". In this context we still make reference to the fundamental work Poetics by Aristotle, and to the poem Arte Poética by Niclas Boileau-Despréaux. Afterward, we sequentially tease Sophia de Mello's "Artes poéticas". These are small texts in which the poet makes considerations about her writing process and about her thoughts on poetry. At the same time, some poems by the author are put into discussion, in analytical and comparative terms with her "Arte poéticas", considering the following topics: the desígnios of making poetry, the understanding of the very own poetry, the place and role of the poet, and the relationship that arises between the poetry and the poet. This work will be an opportunity to ponder how some of her poems relate to the ideals of her "Artes poéticas". At first, they will be poetics linked to the accuracy, to the objectivity towards the real, to the rationalized attitudes, to the posture of economy and synthesis in the discourse. However, we observe that in her thinking process about poetry, there are palpable certainties, as well as aspects entangled with intuition and volatility.

Keywords: Art of Poetry. Poetics. Portuguese poetry of the XXth century.

Este ensaio busca identificar, apresentar e discutir conteúdos e conceitos dos cinco textos "Arte poética", de Sophia de Mello Breyner Andresen, por meio de duas abordagens. Em um primeiro momento, será realizada, como pré-requisito, uma breve retomada de significados do termo "arte poética", inclusive sendo tratados alguns pontos da Arte Poética de Horácio, a chamada "Carta aos Pisões". Escrito "nos últimos anos da vida do poeta, provavelmente entre 14-13 a.C", esse texto traduz o seu pensamento literário amadurecido, além de historicamente ter exercido “importante papel na constituição daquilo que se costuma 
entender pela expressão 'teoria clássica da literatura'" (BRANDÃO, 2005, p. 6). Ainda, nesta contextualização, faremos referência à fundamental Poética, de Aristóteles, e ao poema Arte Poética, de Nicolas Boileau-Despréaux, "um definidor da doutrina clássica" (BERRETTINI, 1979, p. 7).

$\mathrm{Na}$ segunda abordagem serão esmiuçados sequencialmente, por meio da análise de suas principais colocações, as "Artes poéticas" dessa poeta portuguesa, textos lidos em eventos ou esparsamente publicados em revistas, ao modo de pequenos ensaios ou breves narrativas reflexivas, nos quais a autora tece considerações sobre seu processo de escrita, seu pensamento sobre poesia, e até mesmo acerca das origens de sua arte e maestria, estas, remotas à infância ou remontadas com lembranças.

Concomitantemente, buscar-se-á trazer à discussão alguns poemas da própria Sophia de Mello Breyner Andresen, em termos tanto analíticos quanto comparativos às suas "Artes poéticas", tendo em vista os tópicos apresentados dos desígnios do fazer poesia, do entendimento da própria poesia, do lugar e do papel do poeta, assim como da relação que se coloca entre ambos, poesia e poeta. Será uma oportunidade para ponderar de qual forma - uma corroboração ou uma contradição - seus poemas, mesmo 
que em brevíssima seleção, se relacionam com o ideário de suas "Artes poéticas".

A princípio, serão poéticas relacionadas com a exatidão, a objetividade frente ao real, a atitude racionalizada, a postura de economia e síntese no discurso. Entretanto, veremos que no pensamento sobre sua poesia há certezas palpáveis, como também aspectos cercados por intuição e volatilidade. O percurso de uma sintética e pontual retrospectiva do conceito inicial de "arte poética" e a leitura de uma seleção de poemas da autora permearão essa sondagem pelo sentido das "Artes poéticas" de Sophia de Mello Breyner Andresen.

\section{QUESTÕES DE ARTES POÉTICAS: AO MODO DE BREVE INTRODUÇÃO: ALGUMAS DEFINIÇÕES GERAIS DE “ARTE POÉTICA"}

Façamos algumas observações e digressões a respeito do termo "arte poética", pois entendemos necessário tal retrospecto a fim de, com este breve suporte teórico, sentirmo-nos mais embasados para comentar os cinco textos intitulados "Arte poética", da escritora portuguesa Sophia de Mello Breyner Andresen. Da mesma forma, como os textos em questão da autora receberam o título "Arte poética", julgamos fundamental, ainda que sucinta, uma pesquisa de contexto do termo. 
De modo geral, "arte poética" significa um conjunto de orientações e métodos, ou mesmo um compêndio de preceitos ou regras, os quais culminem em modos de entender e compor textos que em sua escrita se designam no gênero poesia.

Mais abrangente, segundo Augenot ${ }^{1}$, "poética" igualmente é um termo referenciado nos estudos literários, tendo como algumas de suas definições, primeiro, na palavra utilizada por Todorov como "sinônimo de 'ciência' ou 'teoria da literatura': disciplina encarregada de explorar 'essa propriedade singular que faz a singularidade do facto literário: a literariedade'". Em segundo lugar, ainda de acordo com o referido autor, a poética seria uma ciência cujo objeto, simplesmente, é a poesia. Por fim, essa última definição parcialmente se aproxima dos referidos textos da autora Sophia de Mello Breyner Andresen: a poética contempla não exatamente uma disciplina objetiva, embora tenha a ver com a qualidade do que é literário, mas designa uma variedade reunida de princípios estéticos, dispostos implícita ou explicitamente, que encabeça a obra de um autor (ou mesmo de um grupo ou geração).

1 Todas as definições neste parágrafo e no anterior, relacionadas à "Arte Poética" e "Poética" têm como referência Marc Augenot (Glossário da Crítica Contemporânea, Lisboa, Editorial Comunicação, 1984), que se encontra na seguinte ligação "Arte Poética" do Ciberdúvidas da Língua Portuguesa: https://ciberduvidas.iscte-iul.pt/consultorio/perguntas/ arte-poetica/23069. 
Não se esqueça de que a obra denominada Poética, de Aristóteles (384 a.C.-322 a.C.), é fundamental na história da teoria da literatura. Segundo Maria Helena da Rocha Pereira, a partir dela "toda a teoria literária afinal ascende" e "os especialistas das Literaturas Modernas ocidentais [...] têm necessariamente este texto como ponto de partida das suas reflexões teóricas" (2018, p. 5). O texto aristotélico se funda e se desenvolve em três partes essenciais: "uma de introdução em que a mimesis surge logo como o conceito fundamental em que assenta a actividade poética", "outra sobre a tragédia", "e outra ainda sobre a epopeia" (PEREIRA, 2018, p. 9). A noção de imitação (mimesis) estará presente em todo o livro, encontrando-se "na epopeia e na tragédia e também na comédia e no ditirambo, bem como em grande parte na música da flauta e da cítara" e é realizada "pelo ritmo, pela linguagem e pela melodia" (PEREIRA, 2018, p. 10).

Segundo Rebello, Horácio (65 a.C.-8 a.C.) "divulga as ideias aristotélicas e reitera suas proposições" (2014, p. 274). Sua Arte Poética, ou Carta aos Pisões, "historicamente exerceu importante papel na constituição daquilo que se costuma entender pela expressão 'teoria clássica da literatura'" (BRANDÃO, 2005, p. 6). Brandão contempla em sua análise das posições de Horácio o entendimento de que a ação do 
artista é algo racional, objetivo (e, em especial neste quesito, os textos "Arte poética" de Sophia de Mello se assemelham, como veremos a seguir), e exige esforço e dedicação para se chegar a um resultado planejado, distante de uma mentalidade na qual se imagina uma obra nascida por uma “inspiração” momentânea:

Não é um dom imaterial, surgido do nada, pela inspiração subjetiva. Não é um estado de transe do artista. A obra possui uma racionalidade objetiva. É uma construção que tem como fatores estruturantes a unidade e a ordem que exigem do artista o uso da razão, muito trabalho e disciplina. A obra não pode resultar do acaso ou da improvisação. Deve obedecer a um plano, que é executado com precisão até a finalização. Neste processo, deve-se submeter o trabalho a uma rigorosa crítica e refazê-lo tantas vezes quantas forem necessárias. Observe-se que este é um elemento mediador entre a natureza e a arte. Outro elemento de mediação consiste na imitação dos modelos tradicionais, ou seja, a retomada de modelos já consagrados pelo uso. (REBELLO, 2014, p. 274)

No que diz respeito ao poema do teórico do classicismo francês Boileau (1636-1711), Arte Poética, tal qual a Poética de Aristóteles trata-se de uma "reflexão sobre obras-primas anteriores, e não um código com leis a serem seguidas pelos renomados autores que já então haviam composto suas imortais criações" (BERRETINNI, 1979, p. 8). As ideias 
que divulgava eram bastante conhecidas pelos instruídos: "a arte literária é uma imitação da natureza, sendo pois a verdade o seu ideal - o homem na sua verdade eterna; $a$ arte não pode prescindir da razão" (BERRETINNI, 1979, p. 8). De modo que, como também podemos constatar pelos elementos anteriormente mencionados desta seção, "nada inventou Boileau no seu poema didático-artístico; seguiu modelos antigos como Aristóteles [...] Longino, Quintiliano, mas sobretudo Horácio, na sua Epístola aos Pisões [...] a que a tradição deu o nome de Arte Poética" (BERRETINNI, 1979, p. 8).

Apresenta-se a obra em quatro cantos, sendo no primeiro explicitados os "princípios gerais que devem nortear o métier do poeta" (BERRETINNI, 1979, p. 10). Vejamos alguns deles. Segundo a tradução de Berrettini, o poeta deve: "sentir autêntica inspiração (v. 1-26), ter em elevado apreço a razão (v. 27-38), evitando excessos, como o preciosismo (v. 39-48), a prolixidade (v. 49-63), o desequilíbrio no verso (v. 64-68), a monotonia no tom (v. 69-78)" (1979, p. 10). Os demais cantos focalizam os gêneros secundários (como a elegia, a ode, o soneto, o madrigal, a balada etc.), os grandes gêneros literários (a tragédia, a comédia e a epopeia), sendo o último canto reservado aos seus "conselhos de bom senso $e$ de moralidade aos que pretendem cultivar a poesia". 


\section{A ARTE POÉTICA DE HORÁCIO}

Resumidamente, na Ars Poetica, texto do poeta clássico Horácio que consiste em uma carta dirigida aos Pisões ${ }^{2}$, é realizada uma composição de regras para a poesia dramática. Assim, por meio de um pensamento sobre a criação da arte, Horácio determina conceitos voltados ao classicismo, ao mesmo tempo em que "renova e enriquece a visão sobre a criação artística que, no século V a.C., Aristóteles deixara indicado em sua Poética" (REBELLO, 2014, p. 268). Ao prescrever motivações éticas para a prática da literatura, colocam-se seus preceitos sobre poesia, criação literária e formação do poeta (REBELLO, 2014, p. 259). Como lembra Rebello, é sua obra mais extensa, que, ao celebrar os mestres gregos, "explica a dificuldade e seriedade da arte da poesia e procura dar conselhos técnicos aos poetas iniciantes" (2014, p. 268).

Rebello ressalta que, escrevendo conforme o "espírito de sua época", Horácio procura seus modelos na tradição. E, ao buscar esses modelos e convulsionar, entretanto, a um só tempo, "a ordem anterior", seu texto ganha inovação porque

2 Brandão resume alguns dos pilares do pensamento de Horácio, ao lembrar que o autor havia, antes da Arte Poética "composto seis poemas onde tratava de problemas literários, três sátiras $(I, 4 ; I, 10 ; I I, 1)$ e três epístolas $(I, 19 ; I I, 1 ; I, 2)$ ". E complementa dizendo que "algumas das posições aí assumidas serão depois retomadas e aprofundadas na Arte Poética, mas é de se notar que revelam já certas direções básicas de seu pensamento: a procura de perfeição, a busca do equilíbrio expressivo, a valorização da poesia contemporânea, a limitação da audiência como critério do gosto etc" (BRANDÃO, 2005, p. 6). 
"possibilita uma leitura diferente daqueles que o precederam e, desse modo, é capaz de revitalizar a tradição instaurada" (CARVALHAL apud REBELLO, 2014, p. 276).

Nesse sentido, Brandão assinala que um dado em especial do pensamento de Horácio é "a recusa às formas já cristalizadas" (2005, p. 6), sendo que "seu classicismo, ao acentuar o fator trabalho, opõe-se a certas tendências posteriores de ver no classicismo não a busca de perfeição, mas a reprodução das formas de perfeição já atingidas" (BRANDÃO, 2005, p. 6). Ainda, o classicismo horaciano sustenta que "a obra é regida por leis que podem ser apreendidas e formuladas" (BRANDÃO, 2005, p. 7) e a perfeição apenas poderá ser atingida pelo poeta se ele dispuser do "pleno domínio do material criativo, o que não será possível senão através da razão, do trabalho e da disciplina, instâncias diferentes de uma mesma atividade de busca de perfeição artística" (BRANDÃO, 2005, p. 8).

Em Portugal, Horácio encontrou importância na teorização poética do neoclassicismo nesse país (OLIVEIRA, 2000). Em 1790 é publicada uma edição anotada e comentada por Pedro José da Fonseca da Arte Poética de Horácio. Como afirma Oliveira:

Dentre os tratadistas clássicos mais antigos, Francisco José Freire vai conferir grande destaque a Horácio. Se a teoria literária aristotélica, reunida na Poética e na Retórica, 
constituiu o fundamento da criação poética barroca, já no século XVIII, Horácio e a sua Epistula ad Pisones, a qual havia proporcionado à Poética renascentista os seus postulados mais fecundos, assumem uma maior evidência. (OLIVEIRA, 2000, p. 159)

No prólogo da edição, diz Fonseca que "o modelo a seguir em todos os gêneros de literatura deverá ser a Arte Poética" (OLIVEIRA, 2000, p. 161) por "ser esta depois da Poética de Aristóteles a mais excelente obra de crítica, que dos Antigos nos resta, e de que se póde tirar maior utilidade" (OLIVEIRA, 2000, p. 163), "o da razão para todas as artes em geral, e o mesmo bom gosto reduzido a princípios" (OLIVEIRA, 2000, p. 163). A tradução é ilustrada com "escolhidas notas dos antigos e modernos interpretes e com hum commentario critico sobre os preceitos poeticos, lições varias e intelligencia dos logares difficultosos", "como podemos ler na portada da edição de 1790", informa Oliveira (2000, p. 163).

O objetivo do neoclassicismo ${ }^{3}$, movimento de reavivamento de expressões, formas, gêneros e técnicas clássicas oriundas da Portugal do século XVI, colocava-se em contraponto 4 a um dito exagero ornamental barroco:

3 Segundo Oliveira (2000, p. 179), “A poesia de bom gosto caracterizar-se-ia pela harmonia perfeita entre a matéria poética e o ornato estilístico. O uso imoderado deste último punha em risco a sobriedade e a correcção da obra literária. Afinal, o estilo rebuscado e artificioso afirmava-se como um dos males de que enfermava a literatura barroca".

4 Sobre a distinção entre neoclassicismo e barroco em relação à criação literária, sustenta Oliveira que "Da necessidade de definir os fundamentos da criação literária nasce o debate entre 
Perante os excessos barrocos, as consciências começaram a dar conta de como se andava longe dos modelos antigos. A expressão literária, excessivamente guarnecida de ornamentos estilísticos, tornara-se difícil de compreender e até ilógica, sem que os poetas barrocos tivessem consciência de que se apartavam das fontes verdadeiras. Consequentemente, o remédio contra a corrupção das formas e o mau gosto dos temas estava no regresso à lição autêntica definida pelos padrões greco-latinos. (OLIVEIRA, 2000, p. 181)

Portanto, esta seção acerca de algumas conceitualizações de arte poética encerramos com considerações de Aguiar e Silva no que diz respeito ao "intelectualismo clássico" que se revela na "concepção do fenómeno de criação poética" como herdeiro a princípio da tradição aristotélica e horaciana, recusando tal criação como espontânea, o que será importante levar em consideração a fim de a seguir abordarmos os textos de Sophia de Mello Breyner:

De acordo com esta ideia, afirmou Aguiar e Silva: "O intelectualismo clássico revelavase na concepção do fenómeno da criação poética. Herdeiro de uma longa tradição teórica, que procedia de Aristóteles e de Horácio e fora retomada e desenvolvida pela poética quinhentista de matriz aristotélica e horaciana, segundo a qual a techne, a ars, o

o domínio do engenho, que perspectivava o poeta possuído de um furor animi, e a primazia da arte, sinónimo de técnica adquirida em função do estudo e do trabalho. É este um dos conceitos que separa os poetas barrocos dos neoclássicos" (2000, p. 167). 
saber, o trabalho de correcção (limae labor) constituem factores essenciais da criação poética, o classicismo rejeita explicitamente a concepção platónica e neoplatónica do acto criador poético como manifestação de uma 'loucura' ou de um 'furor divino'". (OLIVEIRA, 2000, p. 167-168)

\section{PENSAR E FAZER A POESIA, OU POETA E POESIA - UMA POÉTICA? TEXTOS “ARTES POÉTICAS” EM SOPHIA DE MELLO BREYNER ANDRESEN}

O conjunto de cinco textos "Artes poéticas" ${ }^{\text {, da escritora }}$ Sophia de Mello Breyner Andresen (1919-2004), publicados ou lidos esparsamente entre as décadas de 1960 e 80, contemplam elementos de seu próprio pensamento sobre sua escrita e produção poética. Baseiam-se suas noções em três pontos fulcrais relacionados à poesia: onde está e o que é poesia? como ela a faz? qual o papel do poeta na sociedade? Rabelo faz uma introdução a respeito desses textos:

Sophia escreve e inscreve em suas cinco Artes Poéticas concebidas entre os anos de 1962 e 1989, um percurso poético sem fazer disso um exercício de narcisismo. Nessas cinco artes poéticas, ela nos diz sobre o

5 Conforme descreve Rabelo a respeito do ano e local de publicação de cada um desses textos: "As artes poéticas aparecem numeradas de I a V, sendo a primeira e a segunda, originalmente, publicadas no jornal Távola Redonda, respectivamente, nos anos em 1962 e 1963, antes de comporem o livro Geografia em 1967. A de número III, originalmente, tratase de um texto lido pela poeta em 11 de Julho de 1964, durante almoço promovido pela Sociedade Portuguesa de Escritores, por ocasião da entrega do Grande Prêmio de Poesia atribuído à poeta em função de seu Livro Sexto (1962). Após esse evento, o texto aparece como posfácio à segunda edição do Livro Sexto, em 1964, recebendo o nome de Arte Poética III, somente ao integrar a primeira edição do livro Antologia, em 1968. As Artes Poéticas IV e V integraram, respectivamente, os livros Dual (1972) e Ilhas (1989)" (RABELO, 2012, p. 39). 
que pensa da poesia, sobre como se deu sua formação como poeta, sendo, primeiro, uma "escutadora" de literatura, depois, leitora, para, finalmente, ser uma escritora. (RABELO, 2012, p. 39)

A particularidade que entendemos como de interesse nesses pequenos ensaios é a entonação característica, marcada por certas contradições, com a qual a realidade poética da autora se desprende. Isso porque o modo de pensar sua própria poesia se coloca a partir de tomadas de consciência da mesma realidade objetiva, ou seja, de uma racionalidade no pensamento do ponto de partida da poesia. Tal condição poética, de concretude alicerçada em momentos determinados do real, entretanto, é permeada pelo mistério da subjetividade de como o poema, de fato, se corporifica, se faz: o encontro de algo que já existe e pode ser "pressentido", a impossibilidade de explicação do momento em que se considera o texto como terminado.

\section{"A ÍNTIMA ESTRUTURA DO POEMA": CONFLUÊNCIAS ENTRE TEXTOS “ARTES POÉTICA” E POEMAS DE SOPHIA DE MELLO BREYNER ANDRESEN}

\section{“ARTE POÉTICA I"}

Ao invocar uma loja de barros em Lagos, cidade onde a poeta durante o verão caminha próximo a um muro,

6 Leia-se, na "Arte poética III": "Há um desejo de rigor e de verdade que é intrínseco à íntima estrutura do poema e que não pode aceitar uma ordem falsa" (ANDRESEN, 2010, p. 842). 
procurando uma sombra que não cabe nela, temos o testemunho de uma situação que, em última instância, metaforiza a memória de ser e estar no mundo (e em quais moldes esse elo se realiza), na qual se conjuga a experiência pessoal e por conseguinte a construção de algo, por exemplo, a poesia.

A memória, consubstancializada em ânfora, é a metáfora inicial daquilo que se busca: a materialidade unitária e eterna das coisas. Por meio do passado, que embora não seja colocado como o da Antiguidade Clássica, uma série de elementos dão pistas disso 7 , encontra-se uma pureza de olhar e de formas que se evidenciam e fazem a ligação primordial e vívida entre o homem e o seu estar no mundo:

Olho para a ânfora: quando a encher de água ela me dará de beber. Mas já agora ela me dá de beber. Paz e alegria, deslumbramento de estar no mundo, religação. Olho para a ânfora na pequena loja dos barros. Aqui paira uma doce penumbra. Lá fora está o sol. A ânfora estabelece uma aliança entre mim e o sol. Olho para a ânfora igual a todas as outras ânforas, a ânfora inumeravelmente repetida mas que nenhuma repetição pode aviltar porque nela existe um princípio incorruptível. (ANDRESEN, 2010, p. 838)

7 "O fato de imaginar que a loja de artigos de barro seja uma loja de Creta remete à significação histórico-simbólica, de uma época anterior ao Cristianismo, conferindo-Ihe todo sentido de pureza, precisão e mitificação de um espaço grego. Dentre vários artigos, elege as ânforas de barro-pálido, assentadas pacificamente à espera de significar em outro lugar" (RABELO, 2012, p. 60). 
No entanto, é realizada uma separação, uma distinção marcada, entre o interior cheio de significados da loja e o mundo a ela externo, de princípio carente de peso: "lá fora na rua, sob o peso do mesmo sol, outras coisas me são oferecidas. Coisas diferentes. Não têm nada de comum nem comigo nem com o sol. Vêm de um mundo onde a aliança foi quebrada" (ANDRESEN, 2010, p. 838). Vejamos com pouco mais de vagar esses dois locais, os quais são sopesados em conjunto, ainda que cada um arque com sua substância própria. Isso porque é feita uma comparação entre eles: um tem uma unidade eterna, o outro é corrompível. E a ânfora é o que os pode unir e trazer algum sentido de eternidade e pertença.

A poeta entra na loja dos barros e a mulher que vende os objetos está em sua frente, "rodeada de ânforas" (ANDRESEN, 2010, p. 837). E dos tipos de barro que lá encontra, como se falasse de um conjunto de formas clássicas poéticas continuadas de geração em geração, há:

Barro que desde tempos imemoriais os homens aprenderam a modelar numa medida humana. Formas que através dos séculos vêm de mão em mão. A loja onde estou é como uma loja de Creta. Olho as ânforas de barro pálido poisadas em minha frente no chão. Talvez a arte deste tempo em que vivo me tenha ensinado a olhá-las 
melhor. Talvez a arte deste tempo tenha sido uma arte de ascese que serviu para limpar o olhar. (ANDRESEN, 2010, p. 837)

Então, para ter parte desse mundo "de reino", mundo este que cravara de tradição, de possibilidade de construção, ela leva consigo mesma uma ânfora, parte dele, esse símbolo de união e partilha com o universo:

É por isso que eu levo a ânfora de barro pálido e ela é para mim preciosa. Ponho-a sobre o muro em frente do mar. Ela é ali a nova imagem da minha aliança com as coisas. Aliança ameaçada. Reino que com paixão encontro, reúno, edifico. Reino vulnerável. Companheiro mortal da eternidade. (ANDRESEN, 2010, p. 838)

O outro local, no entanto, o mundo exterior no qual grassa o sol, "pode ser um habitat mas não é um reino" (ANDRESEN, 2010, p. 838). Este é passível de ser conquistado a partir da "aliança que cada um tece" (ANDRESEN, 2010, p. 838), na construção de algo que se consiga realizar com base em um tipo de pureza na natureza, "nas praias de mar verde, no azul suspenso da noite, na pureza da cal, na pequena pedra polida, no perfume do orégão" (ANDRESEN, 2010, p. 838).

Enfim, a construção de algo fundamental, que neste primeiro texto "Arte Poética" se coloca, tem eco na arte que a poeta afirma que "seja / A verdade do teu inteiro estar terrestre". 
Como exemplo, no poema "A casa térrea", a metáfora da construção poética a ser alcançada, com base na verdade interior, será a partir de tal casa "na planície costeira / A meia distância entre montanha e mar" a ser construída "a partir do fundamento" (ANDRESEN, 2010, p. 628).

\section{"ARTE POÉTICA II"}

Por outro lado, nesse texto "Arte poética", a autora afasta a ideia de que a poesia lhe pedisse "uma ciência", "uma estética" ou "uma teoria" (ANDRESEN, 2010, p. 839). Nem mesmo "uma especialização" poderia a ela pedir a poesia, pois "a sua arte é uma arte do ser" (ANDRESEN, 2010, p. 839). É como se a poeta simplificasse ao mínimo a sua concepção de poesia: ser, no mundo, estar; entretanto, nisto reduzindo-se ao essencial.

No poema "Homero" (ANDRESEN, 2010, p. 814) vemos essa noção sintética de poesia alicerçada na vida concreta face a face à consciência do estar no mundo. Deve-se, portanto, "escrever o poema" como? A resposta, em quatro versos livres, três deles em anáfora (com a repetição do início de verso em "Sem que") reúne em especial quatro elementos: natureza, pensamento, homem, vida:

Escrever o poema como um boi lavra o campo

Sem que tropece no metro o pensamento 
Sem que nada seja reduzido ou exilado Sem que nada separe o homem do vivido (ANDRESEN, 2010, p. 814)

Como é "Sem que nada separe o homem do vivido" que o poema procura ser escrito, bem entendemos que a poesia a ela, poeta, pede "uma obstinação sem tréguas, densa e compacta" (ANDRESEN, 2010, p. 839). Mais, a poesia requer da autora não só uma parte, como uma totalidade de si mesma, toda a sua vida atenta, uma lealdade profunda, e mesmo um tipo de consciência que ultrapasse sua razão (daí insistirmos na dualidade de sua arte poética, que se explica racional e ao mesmo tempo a ela resta uma porção de "mistério"; sendo estes dois elementos intercalados como uma dança nos textos se repetindo):

Pede-me antes a inteireza do meu ser, uma consciência mais funda do que a minha inteligência, uma fidelidade mais pura do que aquela que eu posso controlar. Pede-me uma intransigência sem lacuna. Pede-me que arranque da minha vida que se quebra, gasta, corrompe e dilui uma túnica sem costura. Pede-me que viva atenta como uma antena, pede-me que viva sempre, que nunca me esqueça. (ANDRESEN, 2010, p. 839)

Voltando ao que dissemos, sobre as qualidades subjetivas de sua poética em conjunto com uma objetividade de motivos, para Sophia de Mello Breyner Andresen, em sua 
segunda arte poética a poesia é a sua "explicação com o universo", "convivência com as coisas" e "participação no real" (2010, p. 839). Assim, ainda, para a poeta, o poema "não fala de uma vida ideal mas sim de uma vida concreta", aqui colocada na enumeração de elementos, procedimento que também ocorre em diversos poemas, como, por exemplo no citado anteriormente: "ângulo da janela, ressonância das ruas, das cidades e dos quartos, sombra dos muros, aparição dos rostos, silêncio, distância e brilho das estrelas, respiração da noite, perfume da tília e do orégão" (ANDRESEN, 2010, p. 839).

Essa porção de racionalidade inerente à sua poesia é palpável no seu artesanato que molda a linguagem para a feitura do objeto poético, resultando em uma materialidade exterior, decalcada do real. Essa arte requer "especialização, ciência, trabalho, tempo e uma estética", sendo que as palavras não são escolhidas segundo algum tipo de beleza, mas "pela sua realidade, pela sua necessidade, pelo poder poético de estabelecer uma aliança" (ANDRESEN, 2010, p. 840$)^{8}$. Assim, quando isto é afirmado, reitera-se que as

8 Lembre-se que tal "aliança" se remete àquela do texto "Arte poética I" (ANDRESEN, 2010, p. 838). Igualmente, assinala-se que os cinco textos, apesar de parecerem plenamente distintos em seu conteúdo, ainda assim, com sua carga de originalidade, discursam sobre um mesmo assunto, em última instância, como se foram paráfrases com novos sentidos somando-se a cada novo movimento. Ou seja, a realidade poética, a arte poética, da autora é uma e é una, o que vemos são variações sobre o mesmo tema; como um tema musical ao qual são acrescentadas variantes no decorrer de seu desenvolvimento. 
palavras que o poeta diz "nomeiam a sua visão do mundo, a sua ligação com as coisas" (ANDRESEN, 2010, p. 840).

A essas ideias já expostas em parte na primeira arte poética (realidade, aliança, reino), acrescenta-se, ou melhor, esmiúça-se, a noção da poesia como presságio, como marca, como premonição: "E no quadro sensível do poema vejo para onde vou, reconheço o meu caminho, o meu reino, a minha vida" (ANDRESEN, 2010, p. 840).

\section{“ARTE POÉTICA III"}

Dedica-se em sua maior parte o terceiro texto à importante requisição do real e os procedimentos que daí derivam em sua poética: manipulação do que é concreto e objetividade do olhar. A descoberta da presença da realidade é contada rememorativamente, a partir da lembrança de um quarto, frente ao mar, onde havia "poisada em cima duma mesa, uma maçã enorme e vermelha" (ANDRESEN, 2010, p. 841).

Tal descobrimento é colocado em termos pragmáticos, como "nada de fantástico", "nada de imaginário", apenas o próprio real como algo que se elevava a partir do mar, brilhante, da maçã, encarnada: "uma felicidade irrecusável, nua e inteira" (ANDRESEN, 2010, p. 841). A isso, a poeta chama de "objectividade do meu próprio olhar" (ANDRESEN, 2010, 
p. 841). Em "No poema", o qual entendemos especialmente corroborar com essa "Arte poética", a autora desenvolve esse seu posicionamento de decalcar, transferir com a segurança de eternidade, rigor e clareza de sua literatura as possibilidades vulneráveis para si visíveis:

Transferir o quadro o muro a brisa

A flor o copo o brilho da madeira

E a fria e virgem liquidez da água

Para o mundo do poema limpo e rigoroso

Preservar de decadência morte e ruína

$O$ instante real de aparição e de surpresa

Guardar num mundo claro

O gesto claro da mão tocando a mesa. (ANDRESEN, 2010, p. 405)

Há a afirmação objetiva e pessoal de que "sempre a poesia foi [...] uma perseguição do real" (ANDRESEN, 2010, p. 841) $)^{9}$. E Sophia de Mello Breyner, ao explicar que a sua poesia circunda, delimita uma porção de real, tornando-a um fragmento, ainda assinala que a relação que tece com cada um deles tem a justeza que deve ser levada para a relação com o homem:

Um poema foi sempre um círculo traçado à roda duma coisa, um círculo onde o pássaro do real fica preso. E se a minha poesia, tendo

9 Nesse quesito, segundo Felizardo, "Tal efeito acontece, porque Sophia empreende uma mimese dos seres, dos objetos e dos espaços, através de uma completa aderência das palavras aos referentes. É dessa identificação entre signo verbal e coisa que nascerá a claridade, a transparência de seus poemas" (FELIZARDO, 2000, p. 12), e ele acrescenta que "Claro está que tal realismo é apenas aparente. A arte é sempre criação; nunca é o próprio real, mas uma representação, uma 'mímesis'. O poema de Sophia, portanto, é uma captação do sensível transposta para o universo espiritual da criação humana" (FELIZARDO, 2000, p. 57). 
partido do ar, do mar e da luz, evoluiu, evoluiu sempre dentro dessa busca atenta. Quem procura uma relação justa com a pedra, com a árvore, com o rio, é necessariamente levado, pelo espírito de verdade que o anima, a procurar uma relação justa com o homem. Aquele que vê o espantoso esplendor do mundo é logicamente levado a ver o espantoso sofrimento do mundo. Aquele que vê o fenómeno quer ver todo o fenómeno. É apenas uma questão de atenção, de sequência e de rigor. (ANDRESEN, 2010, p. 841)

De forma que, quem enxerga beleza também enxerga, por seu turno, o desigual, o injusto; e, por isso, contempla todo o fenômeno ${ }^{10}$. A poeta é levada a "buscar a justiça pela própria natureza da sua poesia" (ANDRESEN, 2010, p. $841)^{11}$, já que a justiça "se confunde com aquela ordem do mundo onde o poeta quer integrar o seu canto" (ANDRESEN, 2010, p. 842).

No poema "A forma justa", constata-se um desejo permanente de reinvenção do mundo, em versos livres, brancos e levados ao cabo com certa objetividade referencial ("Sei que seria possível construir o mundo justo/

10 Aqui vemos mais uma dualidade nos textos "Arte poética" da autora, esplendor e sofrimento, partes de um mesmo fenômeno: "Confunde-se com a nossa confiança na evolução do homem, confunde-se com a nossa fé no universo. Se em frente do esplendor do mundo nos alegramos com paixão, também em frente do sofrimento do mundo nos revoltamos com paixão. Esta lógica é íntima, interior, consequente consigo própria, necessária, fiel a si mesma. O facto de sermos feitos de louvor e protesto testemunha a unidade da nossa consciência" (ANDRESEN, 2010, p. 842).

11 "E a busca da justiça é desde sempre uma coordenada fundamental de toda a obra poética" (ANDRESEN, 2010, p. 841). 
As cidades poderiam ser claras e lavadas"; "Cada dia a cada um a liberdade e o reino"; "E este é meu ofício de poeta para a reconstrução do mundo" (ANDRESEN, 2010, p. 660). E a palavra "justa" é colocada em seu duplo sentido, o de justiça, mas também o de certa, precisa, perfeita. Nesta última acepção, voltamos àquele desejo inicial da poeta em ponderar com perfeição objetiva a realidade em sua poesia, como lemos nos seguintes versos do mesmo poema:

Sei que seria possível construir a forma justa De uma cidade humana que fosse Fiel à perfeição do universo

Por isso recomeço sem cessar a partir da página em branco

E este é meu ofício de poeta para a reconstrução do mundo.

(ANDRESEN, 2010, p. 660)

Já o sentido de "justa" como "justiça", buscado em sua poética, no primeiro caso citado, e voltando ao que já foi dito sobre ele ser um fundamento para Sophia de Mello Breyner, ele se coaduna com a noção engajada da figura do artista. Segundo a autora, "o artista não é, e nunca foi, um homem isolado que vive no alto duma torre de marfim" (ANDRESEN, 2010, p. 842). Seja lá qual for o conteúdo da obra de um artista, e seja lá qual for a sua postura (de recolhimento ou não), se tal obra se pautar em determinados princípios de verdade, congruência, ela poderá influenciar os leitores e, 
além disso, ser um chamariz da necessidade da dignidade e da liberdade humana:

$\mathrm{O}$ artista, mesmo aquele que mais se coloca à margem da convivência, influenciará necessariamente, através da sua obra, a vida e o destino dos outros. Mesmo que o artista escolha o isolamento como melhor condição de trabalho e criação, pelo simples facto de fazer uma obra de rigor, de verdade e de consciência ele irá contribuir para a formação duma consciência comum. Mesmo que fale somente de pedras ou de brisas a obra do artista vem sempre dizernos isto: Que não somos apenas animais acossados na luta pela sobrevivência mas que somos, por direito natural, herdeiros da liberdade e da dignidade do ser. (ANDRESEN, 2010, p. 842-843)

\section{"ARTE POÉTICA IV"}

Nessa penúltima arte poética, Sophia incursiona pelas suas reflexões acerca do processo de escrita de um poema singular. O que acontece para um poema alcançar sua materialidade? Como é realizado, ou como ainda não se realizou, o seu ordenamento, a sua estruturação final em versos? E mesmo aquilo que não acontece, ou seja, como seria um estado latente de desejo de escrita? São inquietações como essas que a autora ousa abordar e oferecer as suas respostas, na mesma mescla de objetividade e subjetividade (como uma sensação) na linguagem da qual temos discutido ao longo 
dessas artes poéticas. Se lemos nos versos de "No poema", que "No poema ficou o fogo mais secreto / O intenso fogo devorador das coisas / Que esteve sempre muito longe e muito perto" (ANDRESEN, 2010, p. 360), entendemos que o poema oculto, a se desvendar na escrita, tem a qualidade ambígua de estar distante, mas também próximo.

Comparamos essa estrutura com uma escultura que, estabelecida, não fora mais do que "descoberta" por um escultor, como se estivesse desde sempre inerente, dentro, da pedra, do metal, ou de outra matéria a ser esculpida. Como diz a autora nesse quarto texto de arte poética, "O poema aparece feito, emerge, dado (ou como se fosse dado)" (ANDRESEN, 2010, p. 844). Ao rememorar como encontrou a poesia, encontramos um certo caráter sonhador, intuitivo - os poemas seriam como que entidades existentes por si próprias, a espera de transcrição ${ }^{12}$.

Encontrei a poesia antes de saber que havia literatura. Pensava que os poemas não eram escritos por ninguém, que existiam em si mesmos, por si mesmos, que eram como que um elemento do natural, que estavam suspensos, imanentes. E que bastaria estar muito quieta, calada e atenta para os ouvir. (ANDRESEN, 2010, p. 844)

12 "Deixar que o poema se diga por si, sem intervenção minha (ou sem intervenção que eu veja), como quem segue um ditado (que ora é mais nítido, ora mais confuso), é a minha maneira de escrever" (ANDRESEN, 2010, p. 845). 
Por sua vez escrito, resta ao poema a sua organização, e, quando mais se torna necessário, uma ordenação: "algumas vezes o poema aparece desarrumado, desordenado, numa sucessão incoerente de versos e imagens. Então faço uma espécie de montagem em que geralmente mudo não os versos mas a sua ordem" (ANDRESEN, 2010, p. 845). A poeta assinala que, esse processo só é feito depois de o poema "se ter dito até ao fim", pois, se toca "a meio o poema", "nas minhas mãos desagrega-se" (ANDRESEN, 2010, p. 845).

Ao final, fala-se também da não escrita, ou seja, quando não surge um poema, "o branco do papel torna-se hipnótico" (ANDRESEN, 2010, p. 845) ${ }^{13}$, e se instaura um sentimento de que, apesar do vazio, há uma potencialidade de ação criativa a ser preenchida:

Algumas vezes surge não um poema mas um desejo de escrever, um "estado de escrita". Há uma aguda sensação de plasticidade e um vazio, como num palco antes de entrar a bailarina. E há uma espécie de jogo com o desconhecido, o "indito", a possibilidade. (ANDRESEN, 2010, p. 845)

\section{"ARTE POÉTICA V"}

O último texto "Arte poética" relaciona três pontos principais, que conjugam a especificidade da situação em

13 Cf. os versos: "Poema de geometria e silêncio/ Ângulos agudos e lisos/ Entre duas linhas vive o branco" (ANDRESEN, 2010, p. 849). 
que se encontram poeta e poema. O poeta como um ser no anonimato, "despersonalizado"; o poema perpétuo, contínuo; e a modalidade de ligação entre ambos. Ou seja, temos aqui duas componentes, poeta e poema, e veremos qual ferramenta, qual condição, ou condicionamento, é capaz de uni-los. Uma possível resposta dessa poeta a isso também se encontra em seu poema "O dia": "Passa o dia contigo / Não deixes que te desviem / Um poema emerge tão jovem tão antigo / Que nem sabes desde quando em ti vivia" (ANDRESEN, 2010, p. 849).

Sophia de Mello conta na "Arte poética V" que, em sua infância ${ }^{14}$, antes de ser alfabetizada, aprendeu "um antigo poema tradicional português, chamado Nau Catrineta" (ANDRESEN, 2010, p. 848). O ponto crucial é que ela não sabia, tão criança, que os poemas eram mesmo escritos por pessoas, "mas julgava que eram consubstanciais ao universo, que eram a respiração das coisas, o nome deste mundo dito por ele próprio" (ANDRESEN, 2010, p. 848). Nesta rememoração da infância relacionada à poesia, a qual se alinha e se coaduna com a maturidade poética,

14 A respeito dessa questão da infância como marcante no modo de encarar a criação poética, Silva sustenta que "essa forma de escrever poemas, que Sophia identifica a uma herança de sua infância, tem origem no modo como os gregos concebiam a criação poética: os poetas e adivinhos transmitiam aos homens o que Ihes havia sido revelado pelos deuses ou pelas musas. Um verso porém marca a sua distância da Grécia: "como se os deuses o dessem" (grifo nosso). Esta poesia busca resgatar a presença dos deuses, num tempo que sabidamente é o do exílio deles. Como Hölderlin, Sophia se sabe poeta em tempos de indigência" (SILVA, 2007, p. 17-18). 
deve-se dizer, e mesmo com sua arte poética, ainda relembra que:

Pensava também que, se conseguisse ficar completamente imóvel e muda em certos lugares mágicos do jardim, eu conseguiria ouvir um desses poemas que o próprio ar continha em si. [...] No fundo, toda a minha vida tentei escrever esse poema imanente. E aqueles momentos de silêncio no fundo do jardim ensinaram-me, muito tempo mais tarde, que não há poesia sem silêncio, sem que se tenha criado o vazio e a despersonalização. (ANDRESEN, 2010, p. 848)

Portanto, o que une poeta e poema, o que possibilita ao poeta a audição do poema ${ }^{15}$, ou transcrição do poema, é a união de três necessidades: o silêncio, o vazio e a despersonalização. No poema "No deserto", que descreve o embate da poeta com ela própria ("metade de mim cavalo de mim mesma eu te domino / Eu te debelo com espora e rédea") (ANDRESEN, 2010, p. 482), em busca de liberdade e uma unidade, vemos a conjunção da poeta com ela própria,

15 A busca pelo real, assim como a audição e consequente transcrição do poema nele inscrito, em Sophia de Mello Breyner, é suscitada por Silva nos seguintes termos: "A partir dessa 'perseguição do real' surge a definição do poeta como escutador, do fazer versos como estar atento, da escrita do poema como 'caçada no quarto penumbroso', todos esses modos de conceber o fazer poético repetidos ao longo da obra de Sophia e enraizados na tradição grega, que ela recupera à maneira dos românticos, em particular dos alemães".

Silva aproxima a atenção do poeta em busca do poema com uma dita concepção romântica ao afirmar que "Um dos principais teóricos do romantismo alemão, Friedrich Schlegel, num de seus fragmentos afirma: 'Assim como uma criança é, na verdade, algo que se quer tornar um homem, assim também o poema é somente algo natural que se quer tornar obra de arte.' Segundo Sophia, herdando a concepção romântica, bastaria estar atenta para ouvir o poema" (SILVA, 2007, p. 17). 
no vazio do deserto: "Para poder soltar-te livre no deserto / Onde não somos nós dois mas só um mesmo" (ANDRESEN, 2010, p. 482).

E esse deserto "limpo com seu perfume de astros", uma "grande claridade limpa" (ANDRESEN, 2010, p. 482), em que o poeta deve estar solto, é o próprio lugar do qual se destaca o poema, pois é o "espaço interior de cada poema" (ANDRESEN, 2010, p. 482). Portanto, vemos uma simbiose entre poeta e poema, como se habitassem em um mesmo espaço. Os dois últimos versos do poema, assim como essa arte poética da autora, corroboram com tal interação, com tal convivência, por meio da qual se encontra o chamado "poema imanente", latente de encontrar materialidade, que é "luz e fogo perdidos mas tão perto" (ANDRESEN, 2010, p. 482).

\section{CONCLUSÃO: UM PENSAMENTO DE POESIA EM SOPHIA DE MELLO BREYNER ANDRESEN}

Retomando os principais pontos que compreendemos das "Artes poéticas" de Sophia Breyner, o texto "Arte poética I" instaura um momento da memória como essência de uma poética, metaforizada em um objeto em uma loja de barro, a ânfora, que remete ao classicismo. Também codifica a presença do eu no mundo como essencial para a construção poética. 
"Arte poética II" encara a poesia como uma participação do poeta no real, no concreto, e também a poesia como uma marca própria, um presságio.

Enquanto isso, "Arte poética III" estabelece peremptoriamente a presença do real como algo sereno, inexorável, sedutor, o que é descrito na visão de uma maçã e do mar como primeiros elementos de caída de consciência dessa mesma presença. Ainda, ressalta-se a objetividade do olhar para a poesia. Importantemente, coloca-se o fato de que o poeta vê todo o fenômeno, tendo como partes o esplendor e o sofrimento; e, sendo assim, o poeta busca a justiça, que é tida como um elemento fundamental de toda a obra poética. De modo que, devido a isto, o artista é um ser que tem a possibilidade de influenciar a vida e o destino dos outros.

"Arte poética IV", por sua vez, focaliza a singularidade do poema e seu processo de escritura. Um poema, afinal, apenas deve ser encontrado? Situação complementar ao texto de número $V$, que fala sobre o "poema imanente" (ANDRESEN, 2010, p. 848), que aguarda para ser feito. E, ainda, diz sobre o lugar vazio e silencioso como preparação do poeta, este também anônimo, despersonalizado, na feitura do texto. 
Se na Arte Poética de Horácio havia como objetivo a formulação de regras para a poesia dramática, com a exposição de seu ideário sobre a poesia, a criação literária e a formação do poeta, e procurando aconselhar tecnicamente poetas iniciantes, por sua vez renovando o pensamento aristotélico e influenciando outros autores, como vimos, a poética também pode ser tratada, sobretudo contemporaneamente, mesmo que sob influência desses autores fulcrais, como uma matéria mais livre, na qual podem se dispor os desígnios estéticos de um autor ou grupo, relacionados à literariedade da obra em questão.

No caso dos cinco textos "Arte poética", da poeta portuguesa Sophia de Mello Breyner Andresen, há uma série de explicações sobre suas razões poéticas, e se há um tom por vezes vaporoso, enigmático, reverberante, circular e literário nesses textos, com rememorações sobre a infância, pequenas narrativas ou elucubrações, isso cria um contraponto singular e inusitado com a explicação de objetividade e racionalidade instada como uma procura desenfreada pela realidade em seus poemas. Tal busca sugere a concepção de mimese, de imitação verossímil da natureza, princípio fundamental da estética aristotélica e clássica, muito embora não seja tal conceito colocado de forma clara e nominal ${ }^{16}$.

16 Sobre as apropriações diversas da cultura clássica, afirma Rebello de forma ampla que "A cultura ocidental emprega e empregou, nas inúmeras recepções da Antiguidade, o legado clássico como parâmetro para suas próprias formas de representação. A compreensão e 
Nesse sentido, Felizardo afirma que:

A poesia de Sophia, portanto, afirma um neo-classicismo, uma nova vertente da arte como mímesis do real. Nesse aspecto, tal motivação pelo mundo concreto teria raízes no parnasianismo, escola literária cujos autores tinham como obsessão descrever o mundo dos objetos. Todavia, assim como João Cabral, Sophia irá divergir dos postulados dessa escola ao tramar uma obra poética de forte preocupação social e ética. (2012, p. 14)

De fato, junto a essa, digamos, preocupação com o real, deveras tangível no poema, que, no entanto, entendemos como colocada na maior parte dos textos em questão da autora de um modo mais sutil, enigmático, sondando o imperscrutável e a princípio vaporoso aparecimento do texto literário a partir dos esforços do poeta, a preocupação social também se coloca presente, já que é ponderada a poesia acerca de seu entendimento, a respeito de como a realidade nela é rebatida de maneira total. E, se a poeta Sophia de Mello quer ver todo o fenômeno da realidade, e assim o sofrimento irá emergir, por conseguinte, haverá uma busca por justiça, tornando-se o poeta como um ser atento aos acontecimentos desenrolados na sociedade.

utilidade que se dá aos estudos clássicos não é a mesma em momentos sucessivos da história, muda no mesmo passo em que muda a compreensão que temos de nossa própria cultura, no mesmo passo em que mudam as instituições e o todo da sociedade" (REBELLO, 2014, p. 274). 
Abrangendo aquilo que a poeta, assertivamente, sabe, e então descreve, assim como aquilo que ela intui e pressente acerca da criação literária e do seu resultado - o poema -, os textos "Arte poéticas" têm muita liberdade em sua escrita deliberada e imaginativa. Sem a inserção de conceitos fechados, estanques, nem regras, eles são deveras pessoais, fluidos e mensageiros de lembranças, de infância, ensejam reflexões e questões sobre processo criativo. Ainda que ao mesmo tempo propiciem uma essência inteligível para o intangível, não se abstêm de chamar a atenção para o que Ihe foge de explicação e parecem procurar ir até um limite da escrita descrita de um pensamento.

Portanto, temos uma poética que, como vimos em suas convicções, assenta-se fundamentalmente na vontade de intersecção da realidade, na sua transcrição em termos a princípio objetivos por meio do objeto poético, e em sua reflexão social tendo em vista ser este um objeto multifacetado, ao qual o poeta não pode se furtar em não concebê-lo como tal. Em contraponto à racionalidade deliberada de tais posições vigorosas, de como o seu poema é (ou como ela quer que ele seja) unem-se elementos ligados ao mundo da infância e uma tonalidade onírica para lidar com a subjetividade e o esfumado entendimento da 
criação poética em si mesma, ou seja, como o poema se faz, mesmo sendo colocado como algo que é ofertado quase que miraculosamente diante da atenção irrestrita do poeta.

Tendo isso em consideração, a poesia prescinde de um retorno do poeta a si, a poesia pressupõe um estado de pureza tal que nele, nesse "espaço interior de cada poema", a presença do próprio poeta se torne imprescindível apenas da sua, desenvolto dos adereços, "no deserto limpo com seu perfume de astros/ na grande claridade limpa do deserto" (ANDRESEN, 2010, p. 482). É como se a autora pairasse reflexivamente por entre a prosa de seus textos de "Artes poéticas", circularmente, oscilante, bordejando seus temas de eleição e discorrendo, pela originalidade de sua poética de contrários complementares, sobre o impalpável e o sensível, interioridade exterioridade do poema.

\section{REFERÊNCIAS}

ANDRESEN, Sophia de Mello Breyner. Artes poéticas. In: ANDRESEN, Sophia de Mello Breyner. Obra poética. Carlos Mendes de Sousa (Ed.). Lisboa: Caminho, p. 835-844, 2010.

ANDRESEN, Sophia de Mello Breyner. Obra poética. Carlos Mendes de Sousa (Ed.). Lisboa: Caminho, 2010.

ARISTÓTELES; HORÁCIO; LONGINO. A poética clássica. Tradução de Jaime Bruna. São Paulo: Cultrix, 2005.

ARTE POÉTICA. Ciberdúvidas da língua portuguesa. Disponível em: https://ciberduvidas.iscte-iul.pt/consultorio/perguntas/artepoetica/23069. Acesso em: 16 de nov. de 2020. 
BRANDÃO, Roberto de Oliveira. Três momentos da Retórica Antiga. In: ARISTÓTELES; HORÁCIO; LONGINO. A poética clássica. Tradução de Jaime Bruna. São Paulo: Cultrix, 2005.

BERRETTINI, Célia. Prefácio. In: BOILEAU-DESPRÉAUX, Nicolas. A Arte Poética. São Paulo: Perspectiva, p. 7-13, 1979.

BOILEAU-DESPRÉAUX, Nicolas. A Arte Poética. São Paulo: Perspectiva, 1979.

COSTA, Erik Gontijo. Poema do pensamento: as "Artes poéticas" de Sophia de Mello Breyner Andresen. Revista do CESP, Belo Horizonte, v. 38, n. 60, p. 25-41, 2018.

FELIZARDO, Alexandre Bonafim. O lugar do ser: espaço e lirismo em Sophia de Mello Breyner Andresen. Orientadora: Raquel de Sousa Ribeiro. Tese (Doutorado em Letras) - Faculdade de Filosofia, Letras e Ciências Humanas, Universidade de São Paulo, São Paulo, 2012. Disponível em: https://teses.usp.br/teses/disponiveis/8/8150/tde20082012-120435/publico/2012_AlexandreBonafimFelizardo VRev.pdf. Acesso em: 16 de nov. de 2020.

OLIVEIRA, Emília M. Rocha de. A "Arte Poética" de Horácio por Pedro José da Fonseca. Ágora: Estudos Clássicos em Debate, Aveiro, n. 2, p. 155-183, 2000.

PEREIRA, Maria Helena da Rocha. Prefácio. In: ARISTÓTELES. Poética. 6. ed. Tradução e notas de Ana Maria Valente. Lisboa: Fundação Calouste Gulbenkian, 2018.

RABELO, Maria Sonilce Nunes Caetano. O Mar em Sophia: Poética, Tempo e Memória. Orientador: Fernando Segolin. 2012. Dissertação (Mestrado em Literatura e Crítica Literária) - Programa de Estudos Pós-graduados em Literatura e Crítica Literária, Pontifícia Universidade Católica de São Paulo, São Paulo, 2012.

REBELLO, Lúcia Sá. Ars Poetica de Horácio: o texto original. Organon, Porto Alegre, v. 29, n. 56, p. 259-277, jan.-jun. 2014.

SILVA, Sofia Maria de Sousa. Reparar brechas: a relação entre as artes poéticas de Sophia de Mello Breyner Andresen e Adília Lopes e a 
tradição moderna. Orientadora: Cleonice Seroa da Motta Berardinelli. Tese (Doutorado em Letras) - Programa de Pós-graduação em Letras, Pontifícia Universidade Católica de São Paulo, São Paulo, 2007.

Elisa Andrade Buzzo

Mestre (Faculdade de Letras da Universidade de Lisboa - FLUL).

Doutoranda (FLUL).

http://lattes.cnpq.br/3826891172844308

https://orcid.org/0000-0002-0334-9764

elisakrone@campus.ul.pt 